\title{
Assessment of professional competencies of pedagogy students in the conditions of distance learning
}

\author{
Olga Aigunova ${ }^{1 *}$ and Evelina Mariia Salikova ${ }^{1}$ \\ ${ }^{1}$ Moscow City University, Institute of System Projects, Moscow, Russia
}

\begin{abstract}
The subject of the study is the creation of a system for assessing professional competencies and the formation and implementation of this system into pedagogical university students' educational activities in the context of distance learning. The authors aim to implement the evaluation procedure in a new format due to the introduction of the High Alert State in Moscow and, consequently, remote operations. The developers are faced with the task of not only realizing the assessment of professional competencies but also maintaining the openness of the procedure, ensuring the possibility of communicative interaction between students and employers. Based on the analysis of specialized sources and as a result of discussion within the expert community, new assessment tools are proposed, and an appropriate assessment scheme is developed. The procedure is based on a competency-based approach, the development is carried out considering the requirements of the federal state educational standard, as well as the WorldSkills Russia professional skill competitions in the category "Teaching in general and secondary schools". The procedure is tested based on the Moscow City University within the framework of the Moscow Teacher Certificate project for students. The project has been implemented since 2017, however, for the first time the project has been carried out in a remote format. The data obtained during the study make it possible to identify the possibilities of the assessment procedure in the distance learning context and the key features of students' participation in the procedure and determine the most significant organizational aspects. Based on the results of testing, conclusions are made about the advantages and disadvantages of this procedure, both in terms of content and in organizational terms. The prospects for applying the procedure and the necessary improvements in the future are determined.
\end{abstract}

Keywords: assessment of professional competencies, pedagogical university students, remote conditions, educational activities

\section{Introduction}

The Moscow Teacher Certificate project has been implemented at the Moscow City University since 2017 . The graduates studying pedagogical programs take part in the project.

* Corresponding author: aigunovaoa@mgpu.ru 
The purpose of this project is to assess and develop the professional competencies of future teachers and create a system of interaction and cooperation with representatives of educational organizations, aimed at the growth and development of the human resources of the education system in Moscow. However, the assessment and interaction mechanisms implemented within the project are universal and can be applied in other federal subjects [1]. This project contributes to the employment of young teachers in educational organizations with a favorable staff, which is especially important for maintaining the motivation to carry out professional activities at the beginning of their professional path, which, according to international studies, is not always typical [2].

The project procedure traditionally includes three stages. At the first stage, students need to pass a subject examination, which is due to the idea that in the conditions of intellectualization of work activity and its rapid improvement, fundamental knowledge continues to be of great importance for determining professionalism [3]. At the second stage, the contestants need to show their professional competencies during a model training session [4]. The third stage is self-presentation with elements of interviews with employers. All stages are carried out in the full-time format. This procedure allows students to identify shortfalls, gain practical experience in simulated conditions that correspond to real ones, and gain experience in evaluating their own activities and further analyzing the results. Modern researchers note the availability of practice during the period of study as a key condition for teacher training which subsequently determines students' achievements [5].

Due to the spread of a previously unexplored virus, on 11 Mar. 2020, the Director-General of the World Health Organization (WHO) declared a pandemic, which meant the registration of cases of infection with this disease in most countries of the world [6]. At the time, the organization of the second stage of the project was carried out, and the first stage had been completed. In Moscow, at the level of government bodies, it was decided to introduce a high alert mode due to the change in the epidemiological situation [7] and, consequently, impose a lockdown. Thus, during the implementation of the project, its participants and organizers were faced with the need to switch to a remote format.

The need to develop an alternative version of the procedure in a remote format is also actualized by modern conditions, which imply the development of the teacher's competencies in the field of digital tools for organizing educational activities. Due to the development of digital resources and the change in computer technologies, there is a transformation in many types of activities, including in the framework of education [8]. The transition to a remote format is possible through online resources. Therefore, the key requirement of the Digital School project is the creation of a space for online courses through digital technologies, a focus on the active use of computer game elements in education [9]. The use of mobile technologies in education allows one to increase students' motivation and build an interactive educational environment [10]. The development zone of the future teacher focused on the trends in the transformation of education, is the improvement of the design competencies and creation of digital resources [11]. Empirical data demonstrate the difficulties that teachers face when using digital technologies, as well as the educational resources of this process [12]. The traditional approach to the organization of educational activities in the format of the classroom-lesson system does not sufficiently meet the conditions for the development of society, within which the approach is being implemented, which may hinder the modernization of education [13].

\section{Methods}

In the study, we applied the method of analyzing psychological, pedagogical, and methodological Russian and foreign sources. The empirical method includes observation and analysis of the results of the testing and implementation of the assessment procedure. 


\section{Results}

The most significant changes were made to the procedure of the second stage. The changes introduced were based on the self-directed learning approach [14]. To transfer the procedure to a remote format, the participants were invited to prepare a training video lesson and post this material on YouTube. The participants choose the topic and content for the video lesson independently. The recording time was 20 to 25 minutes (timing discrepancy implied penalty points). Materials were evaluated by an expert board which included representatives of educational organizations from the city of Moscow (three experts). The evaluation was carried out via a digital platform by filling out an observation card. This assessment tool made it possible to put into practice a model of one of the distance learning formats. Modern authors highlight both the positive and negative aspects of distance learning [15].

Table 1 contains the comparison of the procedure at the second stage of the project in the full-time and remote formats.

Table 1. Comparative analysis of the second-stage procedure.

\begin{tabular}{|c|c|c|c|c|}
\hline Format & Tool & $\begin{array}{c}\text { Number } \\
\text { of experts }\end{array}$ & $\begin{array}{c}\text { Number of } \\
\text { students }\end{array}$ & $\begin{array}{c}\text { Blocks of assessed } \\
\text { competences }\end{array}$ \\
\hline full-time & $\begin{array}{c}\text { a model lesson with } \\
\text { students }\end{array}$ & 5 & 6 & $\begin{array}{c}\text { Cognitive } \\
\text { Communicative } \\
\text { Functional }\end{array}$ \\
\hline remote & $\begin{array}{c}\text { an instructional video } \\
\text { lesson without } \\
\text { students }\end{array}$ & 3 & none & $\begin{array}{c}\text { Cognitive } \\
\text { Functional }\end{array}$ \\
\hline
\end{tabular}

The criteria for the analysis of video lessons by the experts were interdisciplinary and comprised two blocks, cognitive and functional. The criteria included the assessment of the process of organizing speech, the accessibility of presented information, public speaking skills, building connections with everyday life, and the possibility of applying the knowledge gained in practice. A separate assessment block included the technical side of presenting material, the format of the lesson, lesson structure, and the successful creation of an information environment. Moreover, based on the results of the lesson, the experts were allowed to express the general impression of watching this lesson with a bonus point. The educational practices used in the lesson must meet the modern needs of the digital generation [16]. These criteria make it possible to consider the informational, substantive, and technical aspects of the lesson, identify the advantages and shortfalls, and provide the participant with structured feedback in the form of an individual profile, which includes data on the level for each criterion, which implies a differentiated assessment.

\section{Discussion}

There were 210 students taking part in the assessment procedure and presenting training video sessions. Based on the analysis of the data, it seems possible to highlight the advantages and disadvantages of the remote procedure.

As the advantages of the remote format for the contestants, one can note that there is no influence of students on the course of the lesson; the video lesson is recorded without the participation of students, in contrast to the full-time format. The participant of the procedure can prepare for the recording, make several attempts, and choose the attempt that demonstrates the participant's competence to a greater extent. An advantage for the participants is also the likely disappearance of psychological barriers due to the comfortable conditions for recording the lesson, the absence of the influence of experts' authority, as well as anxiety caused by the unfamiliar environment at the demonstration site. The competitor 
demonstrates in practice their professional competencies and the remote format allows the widest range of employers to get acquainted with the student's capabilities. According to the researchers, practice-oriented teachers are currently are most in-demand in the educational organization [17]. Therefore, the student has a chance to show their professional competencies at the highest level. The remote format entails a change in the goal of the assessment procedure and a transition from identifying the level of a student's professional competencies in conditions close to real ones to determining the student's maximum potential. This approach presupposes greater reliability and practical orientation, as each educational organization offers different conditions for professional activities, however, the potential of the future teacher is significant. This format implies some advantages for the organizers of the procedure, which include: the chance to spread out expert boards in time since the boards view recorded classes which allows them to return to the elements of the training sessions at the most convenient time, carry out a more careful assessment, distribute the workload on the expert, and involve fewer organizers accompanying the procedure.

As for the difficulties faced by students, it was hard to build communication and maintain dynamics in the absence of students.

The organizers faced difficulties in assembling homogeneous assessment boards (that would allow for uniform assessment during the procedure) which indicates the need for more detailed training of experts and elaboration of criteria.

The assessment procedure allows students not only to show the level of their professionalism but also contributes to its development since the procedure involves a practical test of their capabilities and feedback, which in turn meets the demand of the education system indicated by modern researchers for the need to expand opportunities for young teachers' professional development [18].

\section{Conclusion}

The remote format of assessing the professional competencies of future teachers allows one to optimize the procedure in terms of time, material, and human resources. Moreover, this format allows one considering the current trends in the development of education and determining the competencies of future teachers that are not demonstrated within the fulltime format. As a development prospect, it is possible to create a tool that combines the fulltime and remote formats, which will allow competitors to fully show their professional competencies. In the future, to preserve the communicative block of competencies during the remote format of the procedure, it is possible to conduct an online lesson involving students.

\section{References}

1. Prikaz Ministerstva obrazovaniya i nauki No. 1155 "Ob utverzhdenii federalnogo gosudarstvennogo obrazovatelnogo standarta doshkolnogo obrazovaniya" [Decree by the Ministry of Education and Science No. 1155 "On the approval of the federal state educational standard for pre-school education"] (2013). Accessed on: December 16, 2020. [Online]. Available:

https://docs.edu.gov.ru/document/a72db92c851c9f9c33d52d482420b477/download/12 $53 /$

2. OECD, Teaching in Focus - 2015/11 (2015). Accessed on: December 16, 2020. [Online]. Available: https://read.oecd-ilibrary.org/education/supporting-newteachers_5js1p1r881g5-en\#page1

3. O.Yu. Afanaseva, M.G. Fedotova, Vestnik Chelyabinskogo gosudarstvennogo pedagogicheskogo universiteta, 1, 27-34 (2015) 
4. O.A. Aigunova, E.V. Salikova, V.A. Mkrtchyan, Kak otsenit professionalnuyu deyatelnost uchitelya: sovremennyi podkhod [How to assess teachers' professional activities: the modern approach], in Proceedings of the Conference Sovremennoe obrazovanie v megapolise: vektory razvitiya [Modern education in a megapolis: development vectors], 1, 55-65 (Ekon-Inform, Moscow, 2018)

5. National Council for Accreditation of Teacher Education, Transforming Teacher Education through Clinical Practice: A National Strategy to Prepare Effective Teachers (NCATE, Washington, DC, 2010). Accessed on: December 16, 2020. [Online]. Available: http://www.highered.nysed.gov/pdf/NCATECR.pdf

6. WHO, WHO Director General's opening remarks at the media briefing on COVID-19 (WHO, Geneva, 2020). Accessed on: December 16, 2020. [Online]. Available: https://www.who.int/director-general/speeches/detail/who-director-general-s-openingremarks-at-the-media-briefing-on-covid-19---11-march-2020

7. Ukaz mera Moskvy No. 12-UM "O vvedenii rezhima povyshennoi gotovnosti” [Decree by the Mayor of Moscow No. 12-UM "On the introduction of the State of High Alert"] (Moscow, Mayor's Office, Moscow, 2020). Accessed on: December 16, 2020. [Online]. Available: https://www.mos.ru/upload/documents/docs/12-YM.pdf

8. T.N. Noskova, T.B. Pavlova, O.V. Yakovleva, ITS, 4(85), 456-467 (2016). https://doi.org/10.15507/1991-9468.085.020.201604.456-467

9. Ch. Dichev, D. Dicheva, Int J Educ Technol High Educ, 14, 9 (2017). http://doi.org/10.1186/s41239-017-0042-5

10. M. Dimirbilek, Journal of Information technology education, 9, 235-247 (2010). https://doi.org/10.28945/1327

11. E.V. Soboleva, N.L. Karavaev, M.S. Perevozchikova, Vestnik Novosibirskogo gosudarstvennogo pedagogicheskogo universiteta, 7(6), 54-70 (2017). http://dx.doi.org/10.15293/2226-3365.1706.04

12. E.V. Soboleva, M.S. Perevozchikova, PNiO, 5(41), 428-440 (2019). https://doi.org/10.32744/pse.2019.5.30

13. D. Varlamova, D. Sudakov (Eds.), Atlas novykh professii 3.0 [Atlas of new professions 3.0] (Intellektualnaya Literatura, Moscow, 2020)

14. M. Gibbons, The self-directed learning handbook: Challenging adolescent students to excel (Jossey-Bass, San Francisco, 2002). Accessed on: December 16, 2020. [Online]. Available: http://staffnew.uny.ac.id/upload/132326892/pendidikan/maurice-gibbonsself-directed-learning-handbook-challenging-adolescent-students-excel-jossey-bass20.pdf

15. O.Yu. Timofeeva, Munitsipalnoe obrazovanie: innovatsii i eksperiment, 4, 44-45 (2010)

16. V.D. Nechaev, E.E. Durneva, Pedagogika, 1, 36-45 (2016)

17. O.I. Biryukova, Gumanitarnye nauki i obrazovanie, 3(23), 77-81 (2015)

18. M.A. Pinskaya, A.A. Ponomareva, S.G. Kosaretskii, Voprosy obrazovaniya [Educational Studies Moscow], 2, 100-124 (2016). http://doi.org/10.17323/1814-95452016-2-100-124 